Journal of Maternal and Child Health 2016, 1(4): 230-240

https://doi.org/10.26911/thejmch.2016.01.04.04

\title{
Effectiveness of Pregnant Woman Class in The Prevention of Pregnancy Anemia in Banyuwangi, East Java
}

\author{
Yeni Andriani'1), Supriyadi Hari Respati²), Okid Parama Astirin3) \\ 1)Masters Program in Public Health, Universitas Sebelas Maret, Surakarta \\ 2)Department of Obstetrics and Gynecology, Dr. Moewardi Hospital, Surakarta \\ 3)Faculty of Mathematics and Natural Science, Universitas Sebelas Maret, Surakarta
}

\begin{abstract}
Background: In developing countries $40 \%$ of maternal mortality is associated with pregnancy anemia. Pregnancy anemia has negative effect to mothers, before, during, and after delivery. The purpose of this study was determined effectiveness of pregnant woman class in the prevention of pregnancy anemia in Banyuwangi, East Java.

Subjects and Method: This was an analytical observational study with retrospective cohort design. This study was conducted at Benculuk health center, Banyuwangi, East Java. A total of 100 subjects were selected for this study by fixed exposure sampling, consisting of 50 pregnant mothers who participated pregnant woman class and 50 who did not participate pregnant woman class. The dependent variable was pregnancy anemia. The independent variables were participation in the pregnant woman class, maternal education, family income, food myth, and visit to obstetric gynecology specialist. Anemia was measured by spectrophotometer. Other variables were measured by a set of questionnaire. The data were analyze by multiple logistic regression.

Results: Participation in pregnant woman class $(\mathrm{OR}=0.18 ; 95 \% \mathrm{CI}=0.03$ to $1.21 ; \mathrm{p}=0.078)$, maternal education $\geq$ senior high school $(\mathrm{OR}=0.07 ; 95 \% \mathrm{CI}=0.01$ to $0.92 ; \mathrm{p}=0.043)$, and high family income ( $\geq \mathrm{Rp} 1,599,000)(\mathrm{OR}=0.18 ; 95 \% \mathrm{CI}=0.31$ to $1.03 ; \mathrm{p}=0.054)$ decreased the risk of pregnancy anemia. Myth in food restriction $(\mathrm{OR}=4.47 ; 95 \% \mathrm{CI}=0.73$ to $27.51 ; \mathrm{p}=0.106)$ increased the risk of pregnancy anemia. There was no relationship between visit to obstetric and gynecology specialist and the risk of pregnancy anemia $(\mathrm{OR}=0.93 ; 95 \% \mathrm{CI}=0.09$ to $9.17 ; \mathrm{p}=0.952)$.

Conclusion: Participation in pregnant mother class, maternal education, and high family income decrease the risk of pregnancy anemia. Myth in food restriction increase the risk of pregnancy anemia. There is no relationship between visit to obstetric and gynecology specialist and the risk of pregnancy anemia.
\end{abstract}

Keywords: pregnant woman class, pregnancy anemia

\section{Correspondence :}

Yeni Andriani. Masters Program in Public Health, Universitas Sebelas Maret. Jl. Ir. Sutami 36A, Surakarta 57126, Central Java.

\section{BACKGROUND}

$\overline{\text { Indonesian Demographic and Health Sur- }}$ vey (IDHS) in 2012, reported that the maternal mortality rate in Indonesia was still very high at 359 per 100,000 live births. In 2013, the highest percentage of maternal mortality was around 30.3\% (Ministry of Health, 2014). One of the main causes of hemorrhage is anemia in pregnant mothers (Saifuddin, 2007). Anemia gravidarum (anemia in pregnancy) is the condition of mothers with hemoglobin level below $11 \mathrm{~g} \%$ in the first and third trimester or $<10.5 \mathrm{~g} \%$ level in the second trimester. Anemia gravidarum has a bad effect on the mother, both in pregnancy, labor and puerperium. The complications that can be caused due to anemia gravidarum are abortion, premature birth, prolonged labor due to fatigue of the uterine muscles in contracting (uterine inertia), postpartum hemorrhage, shock, infection during labor or postpartum, and severe anemia (hemoglobin <4 g\% ) which causes decompensatio cordis. In addition, 
hypoxia due to anemia can cause shock and maternal mortality during labor (Saifuddin, 2007).

According to the World Health Organization (WHO) in 2008, the prevalence of anemia gravidarum in the world was $41.8 \%$. The prevalence of anemia gravidarum in Asia was $48.2 \%$, in Africa was $57.1 \%$, in America was $24.1 \%$ and in Europe was 25.1\%. In developing countries, there was $40 \%$ of maternal mortality which was related to anemia gravidarum. Based on the study result of the 2013 Basic Health Research (Riskesdas), there were $37.1 \%$ of pregnant mothers who had anemia with almost in the same proportion between in urban areas at $36.4 \%$ and in rural areas at 37.8\% (Ministry of Health, 2013). In East Java Province 2009, the incidence of anemia was $4.88 \%$ and in Surabaya was $12.65 \%$. The frequency of anemia towards pregnant mothers in Banyuwangi Regency reached 51\% (Purwatiningsih in Nikmah, 2012). There were 537 out of 25,682 (2.09\%) of pregnant mothers who suffered from anemia in 2014 (Health Office of Banyuwangi Regency, 2015).

Pregnant mothers who suffered from anemia increased in 2015 by 855 out of 25,216 (3.39\%) of pregnant mothers. Benculuk Community Health Center is one of four Plus Comunity Health Centers (Specialistic Superior Service Providers) and includes the three best community health center in Banyuwangi (Banyuwangi Regency Health Office, 2016). Although it is one of the best community health center in Banyuwangi, the incidence of anemia gravidarum is quite high. The incidence of anemia gravidarum in 2015 was $7.31 \%$. From January to March 2016, the number of pregnant mothers who suffered anemia in the working area of Benculuk community health center were $23.27 \%$ (Benculuk Community Health Center, 2016).
Anemia is a main health problem that afflicts pregnant mothers in developing countries, for example Indonesia. The basic factors which cause anemia gravidarum are low income, lack of knowledge, low education, and socio-cultural factors (Istiarti, 20oo). Low education is one of the basic factors of malnutrition. Low education causes the difficulty in getting a proper job; it has an effect on low income; low income leads to the inability of someone to prepare food both in quality and quantity (Supariasa, 2001).

Local socio-cultural factors also influence anemia. The food distribution on family that is not based on the need for family members growth and development and the restrictions that must be followed by special groups such as pregnant mothers, infants, mothers who are in puerperium is habits, and community behaviors that hinders the creation of a healthy lifestyle in the community. There is a belief which prohibits pregnant mothers to consume certain food in Indonesia because they are considered harmful and neutral or beneficial to fetus or her pregnancy (Citrakesumasari, 2012). In Banyuwangi Regency, dietary restrictions on pregnant mothers is not the only myth which exists, but there is also prohibitions that must not be done by pregnant woman or her husband (Fauzi, 2016).

Good and correct management of pregnancy complications are needed to decrease the prevalence of anemia in pregnant mothers. Prevention of anemia gravidarum is done by maximizing the absorption of iron and nutrients properly and by checking the pregnancy to an obstetric gynecology specialist. The examination aims to detect the risk factors which appear that can interfere the process of pregnancy and labor; for example, if there are genetic factors of anemia in pregnant mothers (Kartiwa, 2015). 
Journal of Maternal and Child Health 2016, 1(4): 230-240

https://doi.org/10.26911/thejmch.2016.01.04.04

The ways to deal with anemia gravidarum are to do blood transfusion and give oral or parenteral iron preparats. In addition, oral therapy can also be done by giving ferrous sulfate iron preparations, ferrous gluconate or Nafobobitrate by $60 \mathrm{mg} /$ day. Giving preparats by $60 \mathrm{mg} /$ day can increase $\mathrm{Hb}$ levels by $1 \mathrm{~g} \%$ per month. The national program recommends a combination of $60 \mathrm{mg}$ of iron and $50 \mathrm{mg}$ of folic acid for anemia prophylaxis (Saifudin, 2007). In addition, the Ministry of Health in Indonesia has held pregnant woman class program which aims to increase knowledge, attitude, and behavior, so that they can understand about pregnancy such as the body changes during pregnancy, complaints about pregnancy and how to deal with them, danger signs of pregnancy, nutritional regulations, and supplement for blood enhancement to overcome anemia in pregnant mothers (Ministry of Health, 2011).

This study aims to analyze the effecttiveness of pregnant woman class in the prevention of pregnancy anemia gravidarum in Banyuwangi Regency.

\begin{tabular}{l}
\hline SUBJECTS AND METHOD \\
\hline This was an analytical observational study \\
with retrospective cohort design. The retro- \\
spective cohort design was conducted using \\
2 groups, namely exposed group and un- \\
exposed group. The exposed group were \\
pregnant mothers who participated preg- \\
nant woman class, while the unexposed \\
group were pregnant mothers who did not \\
participate pregnant woman class. This stu- \\
dy was conducted at Benculuk community \\
health center, Banyuwangi, since July 2016. \\
A total of 100 subjects were selected for this \\
study by fixed exposure sampling, consis- \\
ting of 50 pregnant mothers who participa- \\
ted pregnant woman class and 50 who did \\
not participate pregnant woman class.
\end{tabular}

The data collection technique used attendance list, a set of questionnaire, and spectrophotometer. The data were analyzed by multiple logistic regression.

\section{RESULTS}

The general characteristic of the study subjects showed that from the 100 respondents, most of them were aged 20-35 years (93\%), and most of them were housewives (88\%). The univariate analysis showed that most of them did not experience anemia gravidarum (90\%), 50\% attended pregnant woman class, $50 \%$ did not take pregnant woman class, most of them were highly educated (79\%), most of them had high family income (87\%), some of them believed in the myth in pregnant mothers (66\%), and most of them had visited to obstetric gynecology specialist (83\%). The bivariate analysis which used the Chi Square test can be seen on Table 1.

Based on Chi Square test result, it was found that pregnant woman class was effective to decrease anemia gravidarum, but it was not statistically significant. Mothers who participated in pregnant woman class decreased half risks compared to mothers who did not participate in pregnant woman class. $(\mathrm{OR}=0.64 ; 95 \% \mathrm{CI}=0.17$ to $2.41 ; \mathrm{p}=$ 0.505).

Maternal education had an effect on anemia gravidarum which statistically significant. Mothers who were highly educated were able to decrease the risks of anemia gravidarum by $1 / 8$ times compared to those with low education $(\mathrm{OR}=0.13 ; 95 \% \mathrm{CI}=$ 0.03 to $0.53 ; \mathrm{p}=0.001$ ).

Family income had an effect on anemia gravidarum which statistically significant. High family income could decrease the risks of anemia gravidarum 1/10 times than mothers with low income $(\mathrm{OR}=0.98$; CI 95\% 0.02 to $0.41 ; \mathrm{p}<0.001)$. 
Table 1. The result of bivariate analysis of pregnant woman class, maternal education, family income, myth, and visit to obstetric gynecology specialist towards anemia gravidarum in Benculuk community health center.

\begin{tabular}{|c|c|c|c|c|c|c|c|c|}
\hline \multirow[b]{2}{*}{ Independent Variable } & \multicolumn{4}{|c|}{ Anemia Gravidarum } & \multirow[b]{2}{*}{ OR } & \multicolumn{2}{|c|}{$95 \% \mathrm{CI}$} & \multirow[b]{2}{*}{$\mathbf{p}$} \\
\hline & Normal & $\%$ & Anemia & $\%$ & & $\begin{array}{c}\text { Lower } \\
\text { Limit }\end{array}$ & $\begin{array}{l}\text { Upper } \\
\text { Limit }\end{array}$ & \\
\hline Pregnant woman class & & & & & 0.64 & 0.17 & 2.41 & 0.505 \\
\hline Participated & 46 & $51 \%$ & 4 & $40 \%$ & & & & \\
\hline Not participated & 44 & $49 \%$ & 6 & $60 \%$ & & & & \\
\hline Maternal education & & & & & 0.13 & 0.03 & 0.53 & 0.001 \\
\hline High & 75 & $83 \%$ & 4 & $40 \%$ & & & & \\
\hline Low & 15 & $17 \%$ & 6 & $60 \%$ & & & & \\
\hline Family income & & & & & 0.98 & 0.02 & 0.41 & $<0.001$ \\
\hline High & 82 & $91 \%$ & 5 & $50 \%$ & & & & \\
\hline Low & 8 & $9 \%$ & 5 & $50 \%$ & & & & \\
\hline $\begin{array}{l}\text { Myth in pregnant mo- } \\
\text { ther }\end{array}$ & & & & & 0.75 & 0.19 & 2.86 & 0.673 \\
\hline Disbelieve & 30 & $33 \%$ & 4 & $40 \%$ & & & & \\
\hline Believe & 60 & $67 \%$ & 6 & $60 \%$ & & & & \\
\hline $\begin{array}{l}\text { Visit to obstetric gyne- } \\
\text { cology specialist }\end{array}$ & & & & & 0.15 & 0.04 & 0.61 & 0.003 \\
\hline Visit & 78 & $87 \%$ & 5 & $50 \%$ & & & & \\
\hline No visit & 12 & $13 \%$ & 5 & $50 \%$ & & & & \\
\hline
\end{tabular}

Myth affected anemia gravidarum, but it was not statistically significant. Pregnant mothers who believe in the myths on pregnancy increased the risk of anemia gravidarum by $3 / 4$ times compared to mothers who did not believe with myths on pregnancy $(\mathrm{OR}=0.75 ; \mathrm{CI} 95 \%=0.19$ to $2.86 ; \mathrm{p}$ $=0.673)$.

Pregnant mothers who had pregnancy check up to an obstetric gynecology specialist had an effect on anemia gravidarum which was statistically significant. Pregnant mothers who did check up on their pregnancies to an obstetric gynecology specialist were able to decrease the risks of anemia gravidarum by $1 / 7$ times compared to pregnant mothers who did not have pregnancy check up to an obstetric gynecology specialist $(\mathrm{OR}=0.15 ; 95 \% \mathrm{CI}=0.04$ to $0.6 ; \mathrm{p}=$ o.003). The multivariate analysis with multiple logistic regression is presented in Table 2.

Table 2. The analysis result of multiple logistic regressions of pregnant woman class, maternal education, family income, myth, and visit to obstetric gynecology specialist towards anemia gravidarum in Benculuk community health center.

\begin{tabular}{lcccc}
\multicolumn{1}{c}{ Variable } & \multirow{2}{*}{ OR } & \multicolumn{2}{c}{ CI 95\% } & \multirow{2}{*}{ p } \\
\cline { 3 - 4 } & & Lower Limit & Upper Limit & \\
\hline Participated in pregnant woman class & 0.18 & 0.03 & 1.21 & 0.078 \\
Maternal education $\geq$ Senior High School & 0.07 & 0.01 & 0.92 & 0.043 \\
Family income $\geq$ Minimum wage & 0.18 & 0.31 & 1.03 & 0.054 \\
Believe on pregnancy myth & 4.47 & 0.73 & 27.51 & 0.106 \\
Visit to an obstetric gynecology specialist & 0.93 & 0.09 & 9.17 & 0.952 \\
N observation = 100 & & & & \\
-2 log likelihood = 46.72 & & & & \\
Nagelkerke R Square = 35\% & & & \\
\hline
\end{tabular}


Journal of Maternal and Child Health 2016, 1(4): 230-240

https://doi.org/10.26911/thejmch.2016.01.04.04

Table 2 showed the results of multiple logistic regression analysis about the effectiveness of pregnant woman class on anemia gravidarum by controlling confounding variables such as maternal education, family income, myths in pregnant mother, and visit to an obstetric gynecology specialist.

Table 2 showed that there was an effect of participation in pregnant woman class on the risks of pregnant mothers experiencing anemia gravidarum which statistically close to significant. Pregnant mothers who participated in pregnant woman class had a risk of getting anemia $1 / 5$ times lower than mothers who did not participate in pregnant woman class $(\mathrm{OR}=0.18 ; 95 \%$ $\mathrm{CI}=0.03$ to $1.21 ; \mathrm{p}=0.078$ ).

There was an effect of maternal education on the risks of pregnant mothers experiencing anemia gravidarum which statistically significant. Pregnant mothers with high education ( $\geq$ SHS) had risks of decreesing anemia gravidarum 1/15 times lower than low education $<$ SHS $(\mathrm{OR}=0.07 ; 95 \%$ $\mathrm{CI}=0.01$ to $0.92 ; \mathrm{p}=0.043)$.

There was an effect of family income on the risks of pregnant mothers experiencing anemia gravidarum which statistically significant. Pregnant mothers with high family income ( $\geq \operatorname{Rp} 1,599,000)$ had risks of experiencing anemia gravidarum 1/15 times lower than low family income $(<\mathrm{Rp}$ $1,599,000)(\mathrm{OR}=0.18 ; 95 \% \mathrm{CI}=0.31$ to 1.03; $\mathrm{p}=0.054)$.

There was an effect of myth in pregnant mother about food restrictions on the risks of pregnant mothers experiencing anemia gravidarum which statistically close to significant. Pregnant mothers who believed about food restrictions had risks of experiencing anemia gravidarum 4.5 times higher than mothers who disbelieved about food restrictions $(\mathrm{OR}=4.47 ; 95 \% \mathrm{CI}=0.73$ to $27.51 ; p=0.106)$.

There was no effect of check up to an obstetric gynecology specialist on the risks of pregnant mothers experiencing anemia gravidarum $(\mathrm{OR}=0.93 ; 95 \% \mathrm{CI}=0.09$ to 9.17; $\mathrm{p}=0.952$ ).

The -2 log likelihood value is a parameter which shows the suitability between the multiple logistic regression analysis models and the samples of study data which is analyzed. The -2 log likelihood value in the study was 46.72 , which means that this model was good enough to describe the data or variable relationships in the sample because the value was $<100$.

The Nagelkerke R Square value in this study was $35 \%$, which means that the independent variables, such as the pregnant woman class and the confounding variables of maternal education, family income, the myth in pregnant mother and visit to an obstetric gynecology specialist could explain $35 \%$ of the variation in prevention of anemia gravidarum. The rest was $65 \%$, which explained by other factors out of the model.

\section{DISCUSSION}

\section{The relationship between pregnant woman class and anemia gravida- rum}

The result showed that there was an effect of the participation in pregnant woman class on the risks of pregnant mothers experiencing anemia gravidarum which statistically close to significant. Pregnant mothers who participated in pregnant woman class had risks of experiencing anemia 1/5 times lower than mothers who did not participate in pregnant woman class.

Pregnant woman class is a study group of pregnant mothers with gestational age between 4 to 36 weeks (before delivery) with a maximum number of participants of 10 people that aims to increase knowledge, change attitudes and behaviors of mothers 
to understand pregnancy, body changes and complaints during pregnancy, pregnancy care, labor, puerperium, postpartum family planning, and newborn care. Pregnant woman class is specifically aims to increase understanding, attitudes, and behavior of pregnant mothers about pregnancy through counseling and regulation of nutrition, including the supplement for blood enhancement to overcome anemia (Ministry of Health, 2011).

The study result conducted by Pujaningsih et al. (2013) showed that there was a very significant relationship between pregnant woman class and the obidience of consuming iron supplement $(\mathrm{p}=0.010)$. There was a significant relationship between pregnant woman class and adequate level of iron $(\mathrm{p}=0.043)$. There was also a very significant relationship between the pregnant woman class and hemoglobin level in pregnant mothers $(\mathrm{p}=0.001)$. The result of this study is in line with the study result conducted by Pujaningsih et al. (2013) that pregnant mothers who participated in pregnant woman class were able to increase maternal hemoglobin level in the second and third trimester, therefore, it could prevent the risks of anemia gravidarum.

In this study, it was found that there were 50 pregnant mothers who participated in pregnant woman class $(50 \%)$ and 50 pregnant mothers who did not participate in pregnant woman class (50\%). Pregnant mothers who participated in pregnant woman class and experienced anemia gravidarum were $40 \%$, while pregnant mothers who did not participate in pregnant woman class and experienced anemia gravidarum were $60 \%$. Pregnant mothers who participated in pregnant woman class were expected to increase knowledge, change attitudes and behaviors regarding pregnancy because of the interaction and sharing experiences between one participant and other partici- pants in the pregnant woman class and also between participants and the facilitator. In the implementation of pregnant woman class, the facilitator often provided counseling such as the importance of nutrition to the mother and how to drink supplement for blood enhancement correctly.

The increase of pregnant mothers knowledge about the nutrients that must be consumed and how to drink supplement for blood enhancement correctly can decrease the risks of anemia gravidarum. Food which is consumed during pregnancy should be food that contains lots of protein, such as fish, chicken, meat, eggs, tofu, tempeh, all green vegetables, fruits, and milk for pregnant mothers.

The supplements for blood enhancement which are given during pregnancy are at least 90 tablets. The supplement for blood enhancement must be taken once a day. The supplement for blood enhancement is better to be taken before going to sleep to prevent nausea and the absorption will be better if it is taken with vitamin $\mathrm{C}$, such as orange juice and guava juice. From the counseling, pregnant mothers would increase their knowledge about the importance of nutrition during pregnancy, so that they would be aware of the consumption styles and the risks of anemia could be prevented even though anemia gravidarum were often occured in pregnant mothers.

\section{The relationship between maternal education and anemia gravidarum}

The study result showed that there was an effect of maternal education on the risks of pregnant mothers experiencing anemia gravidarum which statistically significant. Pregnant mothers with high education ( $\geq$ SHS) had risks of experiencing anemia $1 / 15$ times lower than mothers with low education ( $<$ SHS).

Education is the process of changing behavior towards maturity and life impro- 
Journal of Maternal and Child Health 2016, 1(4): 230-240

https://doi.org/10.26911/thejmch.2016.01.04.04

vement. Generally, a pregnant woman who has higher education can balance her consumption pattern than mother who has lower education (Supariasa, 2001).

A study conducted by Fatimah et al. (2011) showed that the prevalence of anemia in pregnant mothers was $41 \%$, where low and moderate anemia $(54.9 \%$ and 43.9\%) generally occurred. It can be concluded that the hemoglobin level of pregnant mothers is related to education, nutritional status, consumption of Fe tablets, and consumption pattern $(\mathrm{p}=0.001 ; \mathrm{R} 2=$ $0.24)$.

This study showed that most of the study subjects who were highly educated ( $\geq$ SHS) were $79 \%$ and few of them who were low educated were $21 \%$. Pregnant mothers who were highly educated and experienced anemia gravidarum were $40 \%$ and pregnant mothers who were low educated and experienced anemia gravidarum were $60 \%$.

A pregnant woman who is highly educated can balance her consumption patterns. A mother who has high knowledge is able to understand more about the importance of nutrients during pregnancy. $\mathrm{Nu}$ trient intakes are needed to maintain maternal health and the growth of fetus. If the nutrition of pregnant mothers is fulfilled, they will not get anemia. These nutrients can contain of high protein, carbohydrates, vitamins, minerals, folate, and iron.

Low-educated mothers are one of the basic factors which cause malnutrition. Generally, mothers only consume high carbohydrates without being balanced with high animal protein, as well as vitamins. Low education causes the difficulty in getting a proper job; it has an effect on low income; and low income leads to the inability of someone to prepare food both in quality and quantity. This will affect them the food selection, the way to process and ma-

nage the food. Malnutrition before pregnancy will affect the nutritional status of the mother during pregnancy. Pregnant mothers with malnutrition status cause anemia.

\section{The relationship between family income and anemia gravidarum}

Based on the study result, it was found that there was an effect of family income on the risks of pregnant mothers experiencing anemia gravidarum which statistically significant. Pregnant mothers with high family income ( $\geq \operatorname{Rp} 1,599,000$ ) had risks of experiencing anemia gravidarum $1 / 15$ times lower than low family income $(<\mathrm{Rp}$ 1,599,000).

According to Seulze (1996), family income is the total income received by each household from several sources after tax. This income is the income which available for families to spend, consume and save. This income can be calculated in one month, namely net income.

The food availability of a family is strongly affected by the level of family income. Low income is an obstacle that causes people are not able to buy and choose the good and various nutritional food (Citrakesumasari, 2012).

A study conducted by Liow et al. (2012) showed that there was a significant relationship between income and anemia ( $\mathrm{p}=$ o.012) and there is no significant relationship between maternal education and ane$\operatorname{mia}(\mathrm{p}=0.72)$.

This study showed that most of the study subjects have high family income ( $\geq$ minimum wage) which was equal to $87 \%$. High family income is easier to determine the food consumed by family members. The high family income is usually increase the quality of food consumed, such as the supply of side dishes. Someone with a high family income will usually spends some of her money to buy food which have high ani- 
mal protein, such as meat, chicken, fish, and eggs. The high animal protein food are very good for consumption during pregnancy because they contain iron which are useful for preventing anemia during pregnancy. In addition, someone with high family income spends some of her money to buy a variety of vegetables and fruits because they contain various vitamins, iron and minerals that are needed for the fetus growth and development.

Someone with low family income is usually pay less attention to the quality of food consumed during pregnancy. Nutrients that contain protein are usually only obtained from vegetable protein which is cheaper than animal protein. They usually prefer to consume side dishes such as tempeh and tofu. They are rarely consume food which contain animal protein due to the limited money they have. The income level determines the type of food will be purchased. Poor people will usually spend some of their extra income on food, while rich people do not spend some of their extra money on food.

\section{The relationship between myth of pregnancy and anemia gravidarum}

The results showed that there was an effect of the myth in pregnant mother about dietary restrictions on the risk of pregnant mothers experiencing anemia gravidarum and statistically close to significant. Pregnant women who believed in the myths about dietary restrictions had 4.5 times greater risks of anemia than mothers who did not believe in the myths.

Local socio-cultural factors also affects anemia. Food distribution in the family that is not based on the need for family members growth and development and taboos that must be followed by specific groups such as pregnant women, infants, and mothers in puerperium is a custom and community behavior that inhibits the crea- tion of a healthy lifestyle in the community (Citrakesumasari, 2012).

A study conducted by Harnany (2006) showed that there were more than half of the respondents carried out taboos on food such as squid, shrimp, sembilang fish, catfish, all types of sea fish, eggs, mutton, pineapple, durian, banana's heart, eggplants, and java sugar. There were more than half of the respondents (70.9\%) had low level of iron adequacy and $\mathrm{C}$ vitamins. Most of respondents (77\%) drank tea once a day, more than half respondents (63.3\%) consumed iron tablets less than the suggestion, and more than half of the respondents (51.9\%) suffered from anemia. The $\mathrm{R}$ square value of 0.599 indicated that the variables studied were variants that contributed to the $\mathrm{Hb}$ levels. The highest contribution by food taboos was $\mathrm{p}=0.001$.

This study showed that most of pregnant mothers who believed in myth on pregnancy were $41 \%$. The pregnant mothers who disbelieved in myth and experienced anemia gravidarum were $40 \%$. The pregnant mothers who believed in myth and experienced anemia gravidarum were $60 \%$.

The myth about pregnancy is mostly trusted by pregnant mothers who are in the working area of the Benculuk Community Health Center because most of them are Javanese and Osing, so they still believe in these myths. They believe that pregnant mothers must speak good words, behave well, do not kill animals, so that the baby will not born disabled. Pregnant mothers also believe that there are certain types of food that should not be consumed during pregnancy. They assume that there are certain food that are considered dangerous for fetus. The family members also recommend to do food restrictions during pregnancy, even though they do not give sanctions.

Most of pregnant mothers must not eat pineapples, mangoes, and durians be- 
Journal of Maternal and Child Health 2016, 1(4): 230-240

https://doi.org/10.26911/thejmch.2016.01.04.04

cause they are believed cause miscarriage and sore eyes on the babies born. Pregnant mothers must not eat conjoined twin bananas because they are believed cause siam twins on the babies born. They must not eat chili and pepper. For animal protein, they must not eat shrimps because they are believed to cause children who walk backwards. They must not eat crabs because they cause children who walk with their buttocks. They must not eat eggs because they are believed cause ulcers on the babies born. They must not consume beef, mutton, and fish too much.

If a pregnant mother abstains from certain foods, it will affect her consumption pattern and the nutrients needed by the pregnant mother decrease. The nutrition of pregnant mother are the important things must be fulfilled during pregnancy. The risk of the fetus health and the pregnant mother will decrease if pregnant mother get balanced nutrition.

Along with the growth of gestational age, the nutritional needs of pregnant women will also increase, especially when the gestational age enters the second trimester. At the second trimester, the fetus grows very rapidly, especially the growth of the brain and its nervous system.

Iron is needed to form the blood, especially forming hemoglobin red blood cells and reducing the risks of pregnant mothers in getting anemia. There is iron in meat, liver, and fish. If pregnant mothers abstain from eating these foods, it can increase the incidence of anemia in pregnant mothers.

\section{The relationship between visit to obstetric gynecology specialist and anemia gravidarum}

The results showed that there was no effect of the visit to obstetric gynecology specialist on the risk of pregnant mothers experiencing anemia gravidarum.

When you find that you are pregnant, check your health condition immediately to to an obstetric gynecology specialist. It aims to detect any risk factors that can interfere with the process of pregnancy and labor, such as the genetic factors in anemia in pregnant mothers. An obstetric gynecology specialist can also do a blood test to calculate hemoglobin levels. If the hemoglobin is low and the normal blood pressure level decreases, it can be marked as having anemia (Kartiwa, 2015).

The results showed that there was no effect of the visit to an obstetric gynecology specialist on the risk of pregnant mothers experiencing anemia gravidarum because the visit to an obstetric gynecology specialist was not a direct factor, but it was an indirect factor which affected anemia incidence. Doing pregnancy check up to an obstetric gynecology specialist only aimed to control and detect pregnancy complications earlier till labor time. It was not a cause of anemia gravidarum.

Variables that increase the risk of pregnant women to have gravidarum anemia is the myth of pregnant women about dietary restrictions.

Based on the analysis result, it can be concluded that the participation in pregnant woman class is effective in decreasing the risk of pregnant mothers to experience anemia gravidarum. Some variables which can decrease the risk factors of pregnant mothers to experience anemia gravidarum are education level and family income. The variable which can increase the risk factors of experiencing anemia gravidarum is myth of food restriction in pregnant mothers.

\section{REFERENCE}

Citrakesumasari (2012). Anemia gizi masalah dan pencegahannya (Nutritional Anemia Problem and prevention). Yogyakarta: Kalika. 
Banyuwangi District Health Office (2015). Profil kesehatan 2014 (Health Profile 2014). Laporan Kepala Dinas Kesehatan Kabupaten Banyuwangi. Retrieved from http://www.depkes.go.id/resources/download/pusdatin/profilkesehatan-indonesia/profil-kesehatan-indonesia-2014.pdf

Banyuwangi District Health Office (2016). Profil kesehatan 2015 (Health Profile 2015). Laporan Kepala Dinas Kesehatan Kabupaten Banyuwangi. Retrieved from http://www.depkes.go.id/resources/download/pusdatin/profilkesehatan-indonesia/profil-kesehatan-Indonesia-2015.pdf

Fatimah S, Hadju V, BaharB, Abdullah Z (2011). Pola konsumsi dan kadar hemoglobin pada ibu hamil di Kabupaten Maros, Sulawesi Selatan (Consumption patterns and hemoglobin level of pregnant women in Maros Regency, South Sulawesi). Makara, 15(1). retriefed from http://www.lib.ui.ac.id/abstrakpdf?id=20328958\&lo kasi=lokal

Fauzi A (2016). Mitos ibu hamil di Banyuwangi. Dinas Kebudayaan dan Pariwisata Kabupaten Banyuwangi (Myths of pregnant mothers in Banyuwangi. Department of Culture and Tourism Banyuwangi Regency).

Harnany AS (2006). Pengaruh tabu makanan, tingkat kecukupan gizi, konsumsi tablet besi dan teh terhadap kadar hemoglobin ibu hamil di Kota Pekalongan tahun 2006 (Influence of food taboos, nutritional adequacy, consumption of iron and tea tablets to the level of hemoglobin of pregnant women in the city of Pekalongan year 2006). Semarang: Universitas Diponegoro Semarang.
Istiarti T (2000). Menanti buah hati (Waiting for babies). Yogyakarta: Media Pressindo.

Kartiwa (2015). Cara mengatasi penyakit anemia pada ibu hamil (How to overcome anemia in pregnant women). Retrieved from: Penyakitanemia.com.

Ministry of Health (2011). Pedoman pelaksanaan kelas ibu hamil (Guidelines for implementing pregnant women). Jakarta. retrieved from http://kesga.kemkes.go.id/images/pedoman/Pedo man\%2oPelaksanaan\%2oKelas\%2oIb u\%20Hamil.pdf

Ministry of Health (2013). Riset kesehatan dasar 2013 (Basic health Research 2013). Jakarta: Badan Penelitian Dan Pengembangan Kesehatan (Health Research and Development Agency). Retrieved from http://www.depkes.go.id/resources/download/general/Hasil\%20Riskesdas\%202013.pdf

Ministry of Health (2014). Infodatin pusat data dan informasi Kementerian Kesehatan RI (Indonesian Health Data Center and information Ministry of Health RI). Jakarta.

Liow FM, Kapantow NH, Malonda N (2012). Hubungan antara status sosialekonomi dengan anemia pada ibu hamil di desa sapa kecamatan tenga Kabupaten Minahasa Selatan (Relationship between socio-economic status with anemia in pregnant women in Sapa Village Tenga District of South Minahasa). Fakultas Kesehatan Masyarakat. Universitas Sam Ratulangi Manado. Bidang Minat Gizi. Retrieved from http://fkm.unsrat.ac.id/wp-content/uploads/2013/o8/M.Liow.pdf

Nikmah N (2012). Hubungan anemia ibu hamil trimester III dengan kejadian berat badan lahir rendah (BBLR) (Relationship anemia trimester-III of 
Journal of Maternal and Child Health 2016, 1(4): 230-240

https://doi.org/10.26911/thejmch.2016.01.04.04

pregnant women with low birth weight incidence (BBLR)). Jurnal Insan Kesehatan, STIKES Insane Se Agung Bangkalan. 4(1).

Pujaningsih S, Rosidi A (2013). Efektifitas program kelas ibu hamil terhadap kepatuhan konsumsi tablet besi, tingkat kecukupan zat besi dan kadar hemoglobin ibu hamil di puskesmas Purwosari Kabupaten Kudus. Fakultas Ilmu Keperawatan dan Kesehatan Universitas Muhammadiyah Semarang.

Saifuddin AB (2007). Buku acuan nasional pelayanan kesehatan maternal dan neonatal (Maternal and neonatal Health Services National reference book). Jakarta: Yayasan Bina Pustaka Sarwono Prawirohardjo.

Seulze C (1996). Analisa pendapatan nasional stabilitas dan pertumbuhan pembangunan: national income analysis (Analysis of national income stability and development growth). Jakarta: Bina Akasa.

Supariasa IDN (2001). Penilaian status gizi (Assessment of nutritional status). Ja

WHO (2008). Worldwide prevalence of anemia 1993-2005. WHO Global Database on Anemia. Geneva, Switzerland: WHO Press. 